\title{
Association of Dopamine Receptor Gene Polymorphisms with the Clinical Course of Wilson Disease
}

\author{
T. Litwin • G. Gromadzka • J. Samochowiec • \\ A. Grzywacz • A. Czlonkowski • A. Czlonkowska
}

Received: 20 February 2012 /Revised: 15 May 2012 / Accepted: 11 June 2012 / Published online: 6 July 2012

(C) SSIEM and Springer-Verlag Berlin Heidelberg 2013

\begin{abstract}
Background: Dopamine receptor D2 (DRD2) polymorphisms are proposed to be important factors in the presentation of neuropsychiatric symptoms in many disorders, including decreased striatum levels of dopamine D2 receptors in Wilson disease. The present study investigated the association between $D R D 2$ gene polymorphisms and clinical manifestation of Wilson disease.

Methods: Analyzing data from 97 symptomatic Wilson disease patients, we investigated the DRD2 gene polymorphisms rs1800497, rs1799732, and rs12364283. We assessed the polymorphisms impact on the phenotypic presentation of the disease.

Results: Generally, the DRD2 gene polymorphisms had no impact on the hepatic or neuropsychiatric clinical presentation of Wilson disease. However, rs1799732 deletion allele carriers with neuropsychiatric symptoms had earlier onset of WD symptoms by almost 6 years compared with individuals without this allele (22.5 vs. 28.3 years; $P<0.05$ ). This unfavorable effect of the rs1799732 polymorphism was even more pronounced
\end{abstract}

Communicated by: Ertan Mayatepek

Competing interests: none declared

T. Litwin $(\bowtie) \cdot$ G. Gromadzka • A. Członkowski •

A. Członkowska

Second Department of Neurology, Institute Psychiatry and

Neurology, Sobieskiego 902 957,

Warsaw, Poland

e-mail: tomlit@medprakt.pl

G. Gromadzka • A. Członkowski · A. Członkowska

Department of Experimental and Clinical Pharmacology, Medical

University, Warsaw, Poland

J. Samochowiec $\cdot$ A. Grzywacz

Department of Psychiatry, Pomeranian Medical University,

Szczecin, Poland among adenosine triphosphatase 7B gene (ATP7B) p.H1069Q homozygous patients, in whom carriership of the deletion allele was related to earlier initial neuropsychiatric manifestation by 14 years (18.4 vs. 32.2 years; $P<0.01)$.

Conclusions: Genetic variation of $D R D 2$, specifically the rs1799732 polymorphism, may produce an earlier clinical presentation of Wilson disease neuropsychiatric symptoms and signs that occur in the course of dopaminergic system impairment due to copper accumulation in the brain. We speculate that this effect may be due to the impact of DRD2 polymorphism on dopamine D2 receptor density, but further studies are needed to understand the mechanisms of such phenotypic effects.

\section{Introduction}

Wilson disease (WD) is an inherited copper metabolism disorder leading to copper accumulation in many tissues (mainly the liver and brain) with secondary damage to affected organs (Roberts and Schilsky 2008; Ala et al. 2007; Ferenci et al. 2003, 2007). WD is associated with a wide spectrum of symptoms (hepatic, neurological, psychiatric, and others) as well as great variability in clinical presentation and outcome (Roberts and Schilsky 2008; Ala et al. 2007; Ferenci et al. 2003, 2007; Schilsky et al. 1994). Although these differences remain largely unexplained, several factors are known to impact clinical presentation of WD, including gender (Schilsky et al. 1994; Litwin et al. 2012a) and genotype (Stapelbroek et al. 2004; Gromadzka et al. 2005, 2006). It is also suspected that WD presentation may be influenced by polymorphisms in the genes encoding prion-related protein, methylenetetrahydrofolate reductase, interleukin-1 receptor antagonist, and apolipoprotein-E 
Table 1 DRD2 polymorphisms and their possible clinical significance

\begin{tabular}{|c|c|c|}
\hline Polymorphism & Possible clinical significance & Comment \\
\hline rs1800497 $A N K K$ TaqIA & $\begin{array}{l}\text { The A1 allele frequency is higher in patients with neuroleptic } \\
\text { malignant syndrome (Suzuki et al. 2001). } \\
\text { The A1 allele is associated with tardive dyskinesia, Parkinson's } \\
\text { disease (data are conflicting), and late onset hallucination } \\
\text { induced by treatment with levodopa (Noble 2003; Makoff } \\
\text { et al. 2000; Olivieri et al. 2000). }\end{array}$ & $\begin{array}{l}\text { The A1 allele may be associated with } \\
\text { decreased D2 receptors in striatum } \\
\text { (Noble 2003). }\end{array}$ \\
\hline rs1799732 - $141 \mathrm{C}$ Ins/Del & $\begin{array}{l}\text { The Del allele frequency is higher in patients with neuroleptic } \\
\text { malignant syndrome (mechanism not known; data } \\
\text { conflicting) (Kishida et al. 2004; Farde et al. 1995). } \\
\text { The Del allele is significantly associated with poorer } \\
\text { antipsychotic drug response (Zhang et al. 2010). }\end{array}$ & $\begin{array}{l}\text { Data are conflicting regarding the impact } \\
\text { on D2 receptors density in striatum } \\
\text { Deletion (Del+) may be associated with } \\
\text { increased number of D2 receptors } \\
\text { (Jonsson et al. 1999) or may have no } \\
\text { impact on DRD2 density (Ritchie and } \\
\text { Noble 2003). }\end{array}$ \\
\hline rs12364283 DRD2 Ex8 & $\begin{array}{l}\text { DRD2 Ex8 A/A genotype is associated with increased anxiety, } \\
\text { depression, and suicide attempts after detoxification treatment } \\
\text { in alcohol-dependent patients, with reduced response to } \\
\text { dopamine D2 agonists (apomorphine) and to D2 antagonists } \\
\text { (tiapride) (Samochowiec et al. 2000). }\end{array}$ & $\begin{array}{l}\text { The E8A/A allele may be associated with } \\
\text { reduced DRD2 expression (Samochowiec } \\
\text { et al. 2000). }\end{array}$ \\
\hline
\end{tabular}

(Merle et al. 2006; Gromadzka et al. 2011a, b; Schiefermeier et al. 2000; Litwin et al. 2012b). Other genes like antioxidant-1 (Atox-1), copper metabolism gene MURR1 domain containing proteins (COMMD), and X-linked inhibitor of apoptosis (XIAP) (Simon et al. 2008; Weiss et al. 2006; Burstein et al. 2005; Weiss et al. 2010) have also been suggested as WD modifiers. Nonetheless, phenotyperelated differences in WD manifestation are still mainly unknown.

In WD, most of the neuropsychiatric symptoms are due to basal ganglia dysfunction secondary to copper accumulation (Magalhaes et al. 1994; Schlaug et al. 1994; Nyberg et al. 1982). Pathology studies in WD revealed reduced striatal dopamine and hydroxylase tyrosine levels (Vallone et al. 2000; Nyberg et al. 1982; Mousseau et al. 1993) and animal studies have indicated decreased dopamine receptor 2 (DRD2) during copper overloading (de Vries et al. 1986). Single photon emission computerized tomography (SPECT) and positron emission tomography (PET) studies have shown postsynaptic dopaminergic deficit (loss of D2 receptors in striatum) in WD patients (Oder et al. 1996; Westermark et al. 1995) as well as presynaptic nigrostratial dopaminergic damage (Jeon et al. 1998). WD patients also exhibit reduced bindings of dopamine ligands to dopamine receptors on lymphocytes probably due to dopamine receptors damage during copper intoxication (Członkowski and Członkowska 1984; Członkowska et al. 1987).

Polymorphisms in the DRD2 gene and the related ankyrin repeat and protein kinase-containing protein $(A N K K)$ gene - including $A N K K$ TaqIA (rs1800497), DRD2 PROM -141 C Ins/Del (rs1799732), and DRD2 Ex8 (rs12364283) - impact the dopamine receptor D2 density in the striatum with a high clinical significance in the etiology of many neuropsychiatric disorders, especially involuntary movements (Table 1) (Wu et al. 2006; Noble 2003; Thompson et al. 1997; Kisihida et al. 2004; Suzuki et al. 2001; Tan et al. 2003; Zhang et al. 2010; Ritchie and Noble 2003; Farde and Nordstrom 1993; Farde et al. 1995, 1997; Tinsley et al. 2009).

We hypothesized that these polymorphisms may represent an important predicting factor for phenotypic manifestations of WD. The aim of the present study was to determine, in a large group of WD patients, the relationships among these three important DRD2-related single nucleotide polymorphisms (SNPs) and WD presentation.

\section{Methods}

We studied 97 WD symptomatic patients (42 men and 55 women) who had received a confirmed diagnosis from the Institute of Psychiatry and Neurology in Warsaw, Poland, between 1988 and 2010. This study was approved by the local ethics committee and informed consent was provided by all study subjects. The diagnoses were based on clinical symptoms, abnormal copper metabolism (decreased levels of serum ceruloplasmin and serum copper, and increased 24-h urine copper excretion), presence of the KayserFleischer ring, and, in many cases, genetic examination. If the diagnosis was not certain, it was confirmed by measuring $\mathrm{Cu}-64$ incorporation into ceruloplasmin after 24 and $48 \mathrm{~h}$. None of the examined patients were treated with neuroleptics or drugs that could interfere with dopamine metabolism (dopamine agonists, levodopa), 
Table 2 SNPs, primers, and PCR products

\begin{tabular}{|c|c|c|c|c|c|c|c|}
\hline SNP ID & Position & Primer and sequence & PCR product & $\mathrm{RE}$ & DNA variant & Allele & Fragment size (bp) \\
\hline \multirow[t]{3}{*}{ rs1800497 } & $11 \mathrm{q} 23.2$ & $\begin{array}{l}\text { F: 5'-CTT GCC CTC TAG } \\
\text { GAA GGA CAT }\end{array}$ & 310 & Taq1 & $\mathrm{T} / \mathrm{C}$ & $\mathrm{T}$ & 310 \\
\hline & $A N K K$ & & & & & $\mathrm{C}$ & 180 \\
\hline & & $\begin{array}{l}\text { R: 5'-ACC TTC CTG AGT } \\
\text { GTC ATC AAC C }\end{array}$ & & & & & 130 \\
\hline \multirow[t]{2}{*}{ rs1799732 } & $11 \mathrm{q} 23.1$ & $\begin{array}{l}\text { F: 5'-CAA CCC TGG CTT } \\
\text { CTG AGT CC }\end{array}$ & 207 & Mval & $-141 \mathrm{ins} / \mathrm{del}$ & $\mathrm{C}$ & 207 \\
\hline & Promoter & $\begin{array}{l}\text { R: 5'-GAG CTG TAC CTC } \\
\text { CTC GGC GAT C }\end{array}$ & & & & - & 177 \\
\hline \multirow[t]{2}{*}{ rs1236428 } & $11 \mathrm{q} 23.1$ & $\begin{array}{l}\text { F: 5'-GCC TGT CCT CCC } \\
\text { CGG CTC TG }\end{array}$ & 349 & Hра II & $\mathrm{A} / \mathrm{G}$ & $\mathrm{A}$ & 349 \\
\hline & Ex 8 & $\begin{array}{l}\text { R: 5'-GGC AGT GAG GAG } \\
\text { CAT GGA GCC AAC }\end{array}$ & & & & $\mathrm{G}$ & 282 \\
\hline
\end{tabular}

as such treatment could produce neuropsychiatric manifestations, such as drug-induced movement disorders.

Symptomatic WD patients were defined as patients with clinical signs of WD at onset and/or diagnosis. The hepatic symptoms and signs were assessed based on a detailed questionnaire that included data on fatigue, weight loss, leg edema, jaundice, abdominal swelling, hematemesis, hemorrhages, and fulminant liver failure. Laboratory examinations included ultrasound examinations of the liver and spleen, gastroscopy, and assessments of aminotransferases, alkaline phosphatase, bilirubin, INR, and albumen that were available from medical history and records. The evaluation of neuropsychiatric symptoms and signs was also based on a detailed questionnaire addressing salivation, dysphagia, speech, writing and gait disturbances, involuntary movements, adynamia, epileptic seizures, mood disorders, anxiety, and cognitive impairment (Litwin et al. 2012a).

The age at WD symptom onset/diagnosis was assessed based on patient history, symptoms and signs of WD, and/ or available medical documentation in addition to clinical and laboratory investigations.

WD genotyping was determined by polymerase chain reaction (PCR) as reported previously (Gromadzka et al. 2005, 2006) and was assessed according to $A T P 7 B$ genotype (homozygous p.H1069Q/p.H1069Q, compound heterozygous p.H1069Q/other mutation, or negative for the p.H0169Q mutation). Polymorphisms were determined by PCR and restriction fragment length polymorphism analysis of $A N K K$ TaqIA (rs1800497), DRD2 PROM -141 C Ins/Del (rs1799732), and DRD2 Ex8 (rs12364283) as previously described (Grandy et al. 1989; Hori et al. 2001; Samochowiec et al. 2000). Investigated SNPs, primers, and PCR products are presented in Table 2. One hundred (50 males and 50 females) unrelated, matched, healthy controls were used for SNP comparison and to check the Hardy-Weinberg equilibrium.

Due to the clinical significance of DRD2 in neuropsychiatric disorders, further analysis included a comparison of the distributions of the three polymorphisms between patients with and without neuropsychiatric symptoms and signs, and between patients with neuropsychiatric presentation and patients with dystonic symptoms (most severe neurologic presentation). All analyses of significance were repeated in the set of patients homozygous for the H1069Q mutation, a more homogenous WD patient group.

Statistical Analysis

All data were analyzed using Statistica version 9. The mean, range, percentage, and SD were noted for descriptive summary statistics. Quantitative variables were compared using the Mann-Whitney $U$ test. Categorical variables were compared between groups using the chi-square test and Fisher's test; $P<0.05$ was considered statistically significant. For the multiple comparisons, hypothesis testing was performed using the Bonferroni correction (the $P$-value divided by the total number of pairwise comparisons) to correct for the chance that in multiple comparisons the null hypothesis would be rejected by chance. For three polymorphisms, the level of significance was equal to 0.008 .

\section{Results}

Polymorphisms and WD Clinical Manifestations

In our group of 97 symptomatic patients, 31 had both neuropsychiatric and hepatic manifestations at onset, 32 had only neurological, and 34 had only hepatic symptoms and signs. In total, 63 patients had neuropsychiatric symptoms; among them, 21 had dystonia.

In WD patients and control subjects, no significant deviation from the Hardy-Weinberg equilibrium form was found for $A N K K$ TaqIA (rs1800497; WD patients, $\mathrm{A} 1 / \mathrm{A} 1=2$, $\mathrm{A} 1 / \mathrm{A} 2=33, \mathrm{~A} 2 / \mathrm{A} 2=62 ;$ control subjects, $\mathrm{A} 1 / \mathrm{A} 1=3$, $\mathrm{A} 1 / \mathrm{A} 2=28, \mathrm{~A} 2 / \mathrm{A} 2=69 ;$ chi-squared $=0.006$, degrees of freedom (d.f). $=1, P<0.093), D R D 2$ PROM $-141 \mathrm{C}$ 
Table 3 Distribution of neuropsychiatric and dystonia symptoms and signs in WD patients according to DRD2 polymorphism

\begin{tabular}{|c|c|c|c|c|c|c|}
\hline \multirow[b]{2}{*}{ Patients symptoms and signs: } & \multicolumn{2}{|c|}{$A N K K$ TaqI (A1 allele) } & \multicolumn{2}{|c|}{ DRD2 PROM -141 C deletion } & \multicolumn{2}{|c|}{$\begin{array}{l}D R D 2 \text { Ex } 8 \text { (A/A vs. A/G } \\
\text { and } \mathrm{G} / \mathrm{G})\end{array}$} \\
\hline & $\begin{array}{l}\text { A1 } \\
(n=35)\end{array}$ & $\begin{array}{l}\text { A2 } \\
(n=62)\end{array}$ & $\begin{array}{l}\text { Del- } \\
(n=83)\end{array}$ & $\begin{array}{l}\text { Del+ } \\
(n=14)\end{array}$ & $\begin{array}{l}\mathbf{A} / \mathbf{A} \\
(n=54)\end{array}$ & $\begin{array}{l}A / G \text { and } G / G \\
(n=43)\end{array}$ \\
\hline Not neuropsychiatric $(n=34)$ & $14(41 \%)$ & $20(59 \%)$ & $31(91 \%)$ & $3(9 \%)$ & $20(59 \%)$ & $14(41 \%)$ \\
\hline Neuropsychiatric $(n=63)$ & $21(33 \%)$ & $42(66 \%)$ & $52(82 \%)$ & $11(17 \%)$ & $34(54 \%)$ & $29(46 \%)$ \\
\hline Neuropsychiatric with dystonia $(n=21)$ & $9(43 \%)$ & $12(57 \%)$ & $18(86 \%)$ & $3(14 \%)$ & $11(52 \%)$ & $10(48 \%)$ \\
\hline Neuropsychiatric without dystonia $(n=42)$ & $12(29 \%)$ & $30(71 \%)$ & $34(80 \%)$ & $8(20 \%)$ & $23(54 \%)$ & $19(46 \%)$ \\
\hline
\end{tabular}

Data do not sum to $100 \%$ due to rounding errors. There were no statistically significant differences according to polymorphism or WD clinical form.

Table 4 Age of symptom onset in patients with presence/absence of neuropsychiatric signs and symptoms according to DRD2 polymorphism

\begin{tabular}{|c|c|c|c|c|c|c|}
\hline \multirow[b]{2}{*}{$\begin{array}{l}\text { Clinical manifestation and age of } \\
\text { symptoms and signs onset }\end{array}$} & \multicolumn{2}{|c|}{$A N K K$ Taq1 (A1 allele) } & \multicolumn{2}{|c|}{$\begin{array}{l}\text { DRD2 PROM -141 C } \\
\text { deletion }\end{array}$} & \multicolumn{2}{|c|}{$\begin{array}{l}D R D 2 \text { Ex } 8(\mathrm{~A} / \mathrm{A} \text { vs. A/G } \\
\text { and } \mathrm{G} / \mathrm{G})\end{array}$} \\
\hline & $\begin{array}{l}\text { A1 } \\
(n=35)\end{array}$ & $\begin{array}{l}\text { A2 } \\
(n=62)\end{array}$ & $\begin{array}{l}\text { Del- } \\
(n=83)\end{array}$ & $\begin{array}{l}\text { Del+ } \\
(n=14)\end{array}$ & $\begin{array}{l}\mathbf{A} / \mathbf{A} \\
(n=54)\end{array}$ & $\begin{array}{l}A / G \text { and } G / G \\
(n=43)\end{array}$ \\
\hline $\begin{array}{l}\text { All WD patients } 25.1 \pm 8.7 \\
(n=97)\end{array}$ & $\begin{array}{r}23.5 \pm 7.6 \\
(n=35)\end{array}$ & $\begin{array}{l}26.09 \pm 9.3 \\
(n=62)\end{array}$ & $\begin{array}{r}25.6 \pm 8.9 \\
(n=83)\end{array}$ & $\begin{array}{r}22.0 \pm 7.0 \\
(n=14)\end{array}$ & $\begin{array}{r}25.1 \pm 8.1 \\
(n=54)\end{array}$ & $\begin{array}{r}25.1 \pm 9.3 \\
(n=43)\end{array}$ \\
\hline $\begin{array}{l}\text { Not neuropsychiatric } 21.2 \pm 8.05 \\
\quad(n=34)\end{array}$ & $\begin{array}{r}20.5 \pm 7.6 \\
(n=14)\end{array}$ & $\begin{array}{r}21.6 \pm 8.4 \\
(n=20)\end{array}$ & $\begin{array}{r}21.2 \pm 8.0 \\
(n=31)\end{array}$ & $\begin{array}{l}20.3 \pm 10.4 \\
\quad(n=3)\end{array}$ & $\begin{array}{r}19.5 \pm 5.5 \\
(n=20)\end{array}$ & $\begin{array}{r}22.4 \pm 9.3 \\
(n=14)\end{array}$ \\
\hline Neuropsychiatric $27.3 \pm 8.4(n=63)$ & $\begin{array}{r}25.5 \pm 7.1 \\
(n=21)\end{array}$ & $\begin{array}{r}28.2 \pm 9.0 \\
(n=42)\end{array}$ & $\begin{array}{r}28.3 \pm 8.5 \\
(n=52)\end{array}$ & $\begin{array}{l}22.5 \pm 6.5^{\mathrm{a}} \\
\quad(n=11)\end{array}$ & $\begin{array}{l}26.3 \pm 9.1 \\
(n=34)\end{array}$ & $\begin{array}{r}28.4 \pm 7.5 \\
(n=29)\end{array}$ \\
\hline
\end{tabular}

${ }^{\text {a }}$ Significant difference in age at onset of symptoms $(P=0.035)$ between $D R D 2$ PROM $-141 \mathrm{C}$ del, Del + positive vs. negative patients.

Ins/Del (rs1799732; WD patients, Ins/Ins $=83, \mathrm{Ins} / \mathrm{Del}=14$, $\mathrm{Del} / \mathrm{Del}=0$; control subjects $\mathrm{Ins} / \mathrm{Ins}=80, \mathrm{Ins} / \mathrm{Del}=20$, Del $/$ Del $=0$; chi-squared $=0.614$, d.f. $=1, P<0.433$ ), and DRD2 Ex8 (rs12364283; WD patients, $\mathrm{A} / \mathrm{G}=52$, $\mathrm{A} / \mathrm{A}=40, \mathrm{G} / \mathrm{G}=5 ;$ control subjects, $\mathrm{A} / \mathrm{G}=43$, $\mathrm{A} / \mathrm{A}=52, \mathrm{G} / \mathrm{G}=5$; chi-squared $=1.234$, d.f. $=1$, $P<0.266)$. We did not detect an impact of these polymorphisms on the clinical manifestation of WD at onset (Table 3).

Polymorphisms and Age at First WD Symptom Onset

The mean age of all patients at the first signs of WD was $25.1 \pm 8$ years (range 7-57 years). We found a significant association only between rs 1799732 polymorphism and age of onset of WD neuropsychiatric symptoms - carriers of the deletion $(\mathrm{Del}+)$ allele of the $-141 \mathrm{C}$ Ins/Del polymorphism presented earlier onset of WD neuropsychiatric signs by 6 years compared with Del - carriers (22.5 vs. 28.3 years; $P=0.035$; Table 4 ).
Homozygous p.H1069Q Patients: Polymorphisms, Clinical manifestation, and Age of Symptom Onset

WD genotyping of 97 symptomatic WD patients revealed that 43 patients were homozygous for the p.H1069Q mutation, 36 patients were compound heterozygous, and 18 patients were negative for the p.H1069Q mutation. We did not detect an impact of polymorphisms on the clinical WD manifestation in p.H1069Q homozygous patients (Table 5). Due to the very small group of patients that were homozygous for p.H1069Q mutations in the dystonic group ( $n=3$ ), we did not assess these patients separately. However, among WD p.H1069Q patients, we detected a statistically significant effect of the DRD2 -141 C Ins/Del polymorphism. In this homogenous group, Del + allele carriers presented earlier onset of any WD symptoms by 9 years (20.1 vs. 29.4 years; $P=0.019$ ); furthermore, the subset of these patients with neuropsychiatic signs presented with symptom onset 14 years earlier (18.4 vs. 32.2 years; $P=0.001$; Table 6 ). 
Table 5 Distribution of neuropsychiatric symptoms and signs in WD patients according to DRD2 polymorphism in 43 p.H1069Q homozygous patients

\begin{tabular}{lllllll}
\hline & ANKK Taq1 (A1 allele) & DRD2 PROM & 141 C deletion & DRD2 Ex 8 (A/A vs. A/G and G/G) \\
\hline $\begin{array}{l}\text { Clinical manifestation (symptoms } \\
\text { and signs) }(\boldsymbol{n}=\mathbf{4 3 )}\end{array}$ & $\begin{array}{l}\mathbf{A 1} \\
(\boldsymbol{n}=\mathbf{1 6})\end{array}$ & $\begin{array}{l}\mathbf{A 2} \\
(\boldsymbol{n}=\mathbf{2 7})\end{array}$ & $\begin{array}{l}\text { Del- } \\
(\boldsymbol{n}=\mathbf{3 6})\end{array}$ & $\begin{array}{l}\text { Del+ } \\
(\boldsymbol{n}=7)\end{array}$ & $\begin{array}{l}\text { A/A } \\
(\boldsymbol{n}=\mathbf{2 4})\end{array}$ & A/G and G/G ( $\boldsymbol{n}=\mathbf{1 9})$ \\
Not neuropsychiatric $(\boldsymbol{n}=\mathbf{1 5})$ & $6(40 \%)$ & $9(60 \%)$ & $13(86 \%)$ & $2(13 \%)$ & $8(53 \%)$ & $7(46 \%)$ \\
Neuropsychiatric $(\boldsymbol{n}=\mathbf{2 8})$ & $10(35 \%)$ & $18(65 \%)$ & $23(82 \%)$ & $5(18 \%)$ & $16(57 \%)$ & $12(42 \%)$ \\
\hline
\end{tabular}

Data do not sum to $100 \%$ due to rounding errors. There were no statistically significant differences according to polymorphism and WD clinical form.

Table 6 Age of symptom onset in all WD patients, and according to the presence/absence of neuropsychiatric symptoms and signs and to DRD2 polymorphism in p.H1069Q homozygous patients

\begin{tabular}{|c|c|c|c|c|c|c|}
\hline \multirow[b]{2}{*}{$\begin{array}{l}\text { Clinical manifestation and age of } \\
\text { symptoms and signs onset (years) }\end{array}$} & \multicolumn{2}{|c|}{$A N K K$ Taq 1 (A1 allele) } & \multicolumn{2}{|c|}{$\begin{array}{l}\text { DRD2 PROM }-141 \mathrm{C} \\
\text { deletion }\end{array}$} & \multicolumn{2}{|c|}{$\begin{array}{l}D R D 2 \operatorname{Ex} 8(\mathrm{~A} / \mathrm{A} \text { vs. } \mathrm{A} / \mathrm{G} \\
\text { and } \mathrm{G} / \mathrm{G})\end{array}$} \\
\hline & $\begin{array}{l}\text { A1 } \\
(n=16)\end{array}$ & $\begin{array}{l}\text { A2 } \\
(n=27)\end{array}$ & $\begin{array}{l}\text { Del- } \\
(n=36)\end{array}$ & $\begin{array}{l}\text { Del+ } \\
(n=7)\end{array}$ & $\begin{array}{l}\text { A/A } \\
(n=24)\end{array}$ & $\begin{array}{l}\text { A/G and } G / G \\
(n=19)\end{array}$ \\
\hline All WD patients $(n=43) 28.1 \pm 9.2$ & $\begin{array}{r}25.5 \pm 7.8 \\
(n=16)\end{array}$ & $\begin{array}{c}29.2 \pm 9.6 \\
(n=27)\end{array}$ & $\begin{array}{c}29.4 \pm 8.8 \\
(n=36)\end{array}$ & $\begin{array}{c}20.1 \pm 6.2^{\mathrm{a}} \\
\quad(n=7)\end{array}$ & $\begin{array}{r}27.8 \pm 8.1 \\
(n=24)\end{array}$ & $\begin{array}{c}27.9 \pm 9.8 \\
(n=19)\end{array}$ \\
\hline $\begin{array}{l}\text { Not neuropsychiatric }(\boldsymbol{n}=\mathbf{1 5}) \\
25.2 \pm 7.6\end{array}$ & $\begin{array}{l}22.6 \pm 8.0 \\
\quad(n=6)\end{array}$ & $\begin{array}{l}27.0 \pm 7.2 \\
\quad(n=9)\end{array}$ & $\begin{array}{l}25.3 \pm 7.6 \\
(n=13)\end{array}$ & $\begin{array}{l}24.5 \pm 10.6 \\
(n=2)\end{array}$ & $\begin{array}{l}27.6 \pm 8.8 \\
\quad(n=8)\end{array}$ & $\begin{array}{l}22.5 \pm 5.4 \\
\quad(n=7)\end{array}$ \\
\hline Neuropsychiatric $(n=28) 29.7 \pm 9.7$ & $\begin{array}{r}27.3 \pm 7.5 \\
(n=10)\end{array}$ & $\begin{array}{c}31.1 \pm 10.7 \\
(n=18)\end{array}$ & $\begin{array}{c}32.2 \pm 8.8 \\
(n=23)\end{array}$ & $\begin{array}{c}18.4 \pm 4.0^{\mathrm{b}} \\
\quad(n=5)\end{array}$ & $\begin{array}{c}30.9 \pm 7.3 \\
(n=16)\end{array}$ & $\begin{array}{c}28.8 \pm 11.3 \\
(n=12)\end{array}$ \\
\hline
\end{tabular}

${ }^{a}$ Statistically significant difference $(P=0.019)$ in age at onset of symptoms between DRD2 PROM $-141 \mathrm{C}$ del, Del + positive and negative patients (all WD patients).

${ }^{\mathrm{b}}$ Statistically significant difference $(P=0.001)$ in age at onset of symptoms between DRD2 PROM $-141 \mathrm{C}$ del, Del + positive and negative patients (patients with neuropsychiatric symptoms and signs).

\section{Discussion}

In the present investigation, we identified a significant impact of the DRD2 PROM -141 C Ins/Del (rs1799732) polymorphism on WD clinical neuropsychiatric presentation. We were thus able to partially confirm our initial hypothesis that changes in dopaminergic neurotransmission due to DRD2 polymorphism could be important for clinical neuropsychiatric manifestation. Carriers of the Del + allele of the $-141 \mathrm{C}$ Ins/ Del polymorphism presented earlier onset of WD neuropsychiatric symptoms by almost 6 years compared with the Del variant. This unfavorable effect of the $-141 \mathrm{C}$ Ins/Del polymorphism was even more pronounced in WD p.H1069Q homozygous patients, as the Del + allele carriers presented earlier onset of any WD symptoms by nearly 9 years and neuropsychiatric symptoms by nearly 14 years. Our analysis suggests that the Del + effect was restricted to neuropsychiatric manifestation. Additionally, we did not find any correlation between WD manifestation and the two other studied polymorphisms ANKK TaqIA (rs1800497) and DRD2 Ex8 (rs12364283). The p.H1069Q effect observed in our study could be explained by the fact that compared to other mutations, p.H1069Q ATP7B exerts a relatively mild effect on functions of ATPase 7B (Stapelbroek et al. 2004; Gromadzka et al. 2005) and it is possible that the WD phenotypes of patients possessing more severe $A T P 7 B$ mutations are modulated by other factors to a lesser degree.

In WD, most neuropsychiatric symptoms are due to basal ganglia copper accumulation and the secondary damage to affected structures (dystonia, parkinsonism, and others) or prefrontal cortex disturbances (Magalhes et al. 1994; Schlaug et al. 1994; Nyberg et al. 1982; Oder et al. 1993; Seniow et al. 2002), as both of these areas involve the dopaminergic system (Vallone et al. 2000). Autopsies and radiological and laboratory investigations of WD cases have found reduced striatal dopamine and hydroxylase tyrosine levels (Nyberg et al. 1982), as well as reduced dopamine D2 receptor density (Oder et al. 1996; Schlaug et al. 1994). However, treatment with dopamine agonists or levodopa had no effect, probably due to the presence of both pre- and postsynaptic dopaminergic damage (Frankel et al. 1989; Jeon et al. 1998). The density of DRD2 postsynaptic receptors tends to increase during anti-copper treatment (Schlaug et al. 1994), suggesting that the 
dopamine D2 receptor pathway may be critical to WD clinical presentation. Furthermore, DRD2 polymorphisms are predictive of the dopamine receptor D2 density in the striatum (Noble 2003; Ritchie and Noble 2003), which may also affect WD neuropsychiatric manifestation.

Based on the previously reported clinical significance of the polymorphisms $A N K K$ TaqIA and DRD2 Ex8 (Table 1), we thought that the decreased DRD2 density in the striatum in TaqI A1 allele carriers or reduced expression of DRD2 in Ex8 A/A genotype may worsen dopaminergic neurotransmission leading to earlier onset of neuropsychiatric WD signs, but our data did not confirm this hypothesis. The ANKK TaqIA and DRD2 Ex8 polymorphisms had no impact on WD clinical presentation. We also did not identify a relationship between dystonic manifestation of WD and ANKK TaqI or DRD2 Ex8 polymorphisms as we had expected. This lack of a detected association may be due to our small patient sample, or there may be a different etiology of neuropsychiatric symptoms in WD via other mechanisms involving DRD2.

Previous reports of the clinical significance of the $D R D 2$ $-141 \mathrm{C}$ Ins/Del polymorphism have been conflicting (Table 1). According to some studies (Jonsson et al. 1999; Zhang et al. 2010) Del + carriers may have higher numbers of DRD2 receptors in the striatum. A decrease of postsynaptic DRD2 is usually observed during WD (Oder et al. 1996; Schlaug et al. 1994), and increase is observed during chelating treatment (Schlaug et al. 1994). According to these observations, we should have found a protective effect of the Del + allele on neuropsychiatric presentation (increased number of DRD2) in WD, but we did not. On the contrary, we found that the Del + genotype accelerated the onset of neuropsychiatric symptoms. This unfavorable effect of the Del + allele may be explained by other mechanisms - like changes in receptor affinity, changes in receptor structure, interactions with other genes or environmental factors, or D2 receptor hyposensitivity, leading to a decreased effect of dopaminergic transmission. Another possible mechanism with such an effect could be connected with the impact of the DRD2 -141 C Ins/Del polymorphism on the number of presynaptic D2 receptors (Vallone et al. 2000). According to such a hypothesis, Del + allele carriers could present increased numbers of such receptors, thus providing WD patients with stimulation of D2 presynaptic receptors with low doses of dopamine, which could further reduce dopamine release and dopaminergic cell firing and finally reduce locomotor functions and lead to neuropsychiatric WD presentation (Vallone et al. 2000). Further studies to confirm such hypotheses are very important, because such information could help establish group of WD patients in whom treatment with higher dose of levodopa would be beneficial (Del + carriers). Future investigations of this topic should include assessment of DRD2 density in radiological studies.

Our study has a few limitations. The first is the small number of patients included and the further limited number of SNPs analyzed. However, it should be noted that WD is a rare disease, and the number of patients in our study is very similar to that in many other WD or DRD2 gene polymorphism studies (Schiefermeier et al. 2000; Kishida et al. 2004). This is the first pilot study of DRD2 gene polymorphism in WD, so we tried to assess the most important $D R D 2$ SNPs in neuropsychiatric disorders (especially movement disorders). Furthermore, data are conflicting regarding the impact of the DRD2 -141 C Ins/Del polymorphism on DRD2 density; without more specific studies (PET), we cannot confirm the etiology of the impact of the Del + allele on WD neuropsychiatric presentation. In the present report, we can only hypothesize about the impact on DRD2 expression based on some previous studies (Zhang et al. 2010; Jonsson et al. 1999), but these possibilities should be further investigated especially in WD.

In summary, our findings suggest that the DRD2 - $141 \mathrm{C}$ Ins/Del polymorphism affects WD neuropsychiatric presentation, probably through disruption of the balance of dopamine neurotransmission that makes these patients more sensitive to basal ganglia intoxication by copper accumulation. Further studies of DRD2 SNPs with dopamine receptor imaging in WD patients are needed to better understand the mechanisms of such phenotypic effects.

\section{Financial Disclosure}

All financial involvement (e.g., employment, consultancies, honoraria, stock ownership or options, grants or patents receiving or pending, royalties) with any organization or entity with a financial interest in or financial conflict with the subject matter or materials discussed in the Submitted Publication material are completely disclosed.

We have no relevant financial interest in the Submitted Publication material.

\section{Conflict of Interest}

The authors declare no potential conflict of interest relevant to this article.

\section{Documentation of Author Roles}

1. Anna Członkowska: research project - conception; manuscript preparation - review and critique

2. Grażyna Gromadzka: research project - execution; statistical analysis - review; manuscript critique review 
3. Tomasz Litwin: research project - conception and organization, execution; statistical analysis - design, execution; manuscript preparation - writing of the first draft, review

4. Jerzy Samochowiec: DRD2 polymorphism analysis

5. Anna Grzywacz: DRD polymorphism analysis

6. Andrzej Członkowski: manuscript review and corrections

\section{References}

Ala A, Walker AP, Askhan K et al (2007) Wilson's disease. Lancet 369:397-408

Burstein E, Hoberg JE, Wilkinson AS et al (2005) (2005) COMMD proteins, novel family of structural and functional homologues of MURR1. J Biol Chem 280(23):22222-22232

Czlonkowski A, Czlonkowska A (1984) Reduced binding of $3 \mathrm{H}$-spiroperidol to lymphocyte in Wilson's disease. Acta Neurol Scand 69:298-301

Członkowska A, Jachowicz-Jeszka J, Członkowski A (1987) [3 H] spiperone binding to lymphocyte in extrapyramidal disease and in aging. Brain Behav Immun 1(3):197-203

De Vries DJ, Sewell RB, Beart PM (1986) Effects of copper on dopaminergic function in the rat corpus striatum. Exp Neurol 91 (3):546-558

Farde L, Nordstrom AL (1993) PET examination of central D2 dopamine receptor occupancy in relation to extrapyramidal syndromes in patients being treated with neuroleptic drugs. Psychopharmacol Ser 10:94-100

Farde L, Hall H, Pauli S, Halldin C (1995) Variability in D2 dopamine receptor density and affinity: a PET study with $[11 \mathrm{C}]$ raclopride in man. Synapse 20:200-208

Farde L, Mack RJ, Nyberg S, Halldin C (1997) D2 occupancy, extrapyramidal side effects and antipsychotic drug treatment: a pilot study with sertindole in healthy subjects. Int Clin Psychopharmacol 12:S3-S7

Ferenci P, Caca K, Loudianos G et al (2003) Diagnosis and phenotypic classification of Wilson's Diseases. Liver Int 23:139-142

Ferenci P, Członkowska A, Merle U et al (2007) Late-onset Wilson's disease. Gastroenterology 12(4):1294-1298

Frankel JP, Hughes A, Lees AJ, Stern GM, Walshe JM (1989) Use of apomorphine to test for dopamine responsiveness in Wilson's disease. Lancet 334:801-802

Grandy DK, Litt M, Allen L et al (1989) The human dopamine D2 receptor gene is located on chromosome 11 at q22-q23 and identifies Taq1 RFLP. Am J Hum Genet 45:778-785

Gromadzka G, Rudnicka M, Chabik G, Przybyłkowski A, Członkowska A (2011a) Genetic variability in the methylentetrahydrofolate reductase gene (MTHFR) affects clinical expression of Wilson's Diseases. J Hepatol 55(4):913-919

Gromadzka G, Czlonkowska A (2011b) Influence of IL-1RN intron 2 variable number of tandem repeats (VNTR) polymorphism on the age at onset of neuropsychiatric symptoms in Wilson's disease. Int J Neurosci 121(1):8-15

Gromadzka G, Schmidt HH, Genschel J et al (2006) The p.H1069Q mutation in ATP7B and biochemical parameters of copper metabolism and clinical manifestation of Wilson's disease. Mov Disord 21:245-248

Gromadzka G, Schmidt HH, Genschel J et al (2005) Frameshift and nonsense mutations in the gene for ATPase7B are associated with severe impairment of copper metabolism and with an early clinical manifestation of Wilson's disease. Clin Gen 68:524-532
Hori H, Ohmori O, Shinaka T, Kojima H, Nakamura J (2001) Association between three functional polymorphisms of dopamine D2 receptor molecular variant with schizophrenia. Am J Med Genet 105:774-778

Jeon B, Kim JM, Jeong JM et al (1998) Dopamine transporter imaging with [123I]-beta-CIT-demonstrates presynaptic nigrostriatal dopaminergic damage in Wilson's disease. J Neurol Neurosurg Psychiatry 65:60-64

Jonsson EG, Nothen MM, Grunhage F et al (1999) Polymorphisms in the dopamine $\mathrm{D} 2$ receptor gene and their relationships to striatal dopamine receptor density of healthy volunteers. Mol Psychiatry 4:290-296

Kishida I, Kawanishi C, Furuno T, Kato D, Ishigami T, Kosaka K (2004) Association in Japanese patients between neurleptic malignant syndrome and functional polymorphisms of the dopamine D2 receptor gene. Mol Psychiatry 9:293-298

Litwin T, Gromadzka G, Czlonkowska A (2012a) Gender differences in Wilson's Disease. J Neurol Sci 312(1-2):31-35

Litwin T, Gromadzka G, Czlonkowska A (2012b) Apolipoprotein E gene (APOE) genotype in Wilson's disease: impact on clinical presentation. Parkinsonism Relat Disord 18:367-369

Magalhes ACA, Caramelli P, Menezes JR, Lo L, Bacheschi L (1994) Wilson's disease: MRI with clinical correlation. Neuroradiology 36:97-100

Makoff AJ, Graham JM, Arranz MJ et al (2000) Association study of dopamine receptor gene polymorphisms with drug induced hallucinations in patients with idiopathic Parkinson's disease. Pharmacogenetics 10:43-48

Merle U, Stremmel W, Gesner R (2006) Influence of homozygosity for methionine at codon 129 of the human prion gene on the onset of neurological and hepatic symptoms in Wilson's disease. Arch Neurol 63:982-985

Mousseau DD, Perney P, Layrargues GP, Butterworth RF (1993) Selective loss of pallidal D2 receptor in hepatic encephalopathy. Neurosci Lett 162:192-196

Noble EP (2003) D2 dopamine receptor gene in psychiatric and neurologic disorders and its phenotypes. Am J Med Genet B Neuropsychiatr Genet 116B:103-125

Nyberg P, Gottfries CTG, Homgreen G, Perrson S, Roos BE, Winblad B (1982) Advanced catecholaminergic disturbances in the brain in a case of Wilson's disease. Acta Neurol Scand 65:71-75

Oder W, Brucke T, Kolleger H, Spatt J, Asenbaum S, Deedke L (1996) Dopamine receptor binding is reduced in Wilson's disease: correlation of neurological deficits with striatal I-Iodobenzamide binding. J Neural Transm 103:1096-1103

Olivieri RL, Annesi G, Zappia M, Civitelli D (2000) The dopamine D2 receptor gene is a susceptibility locus for Parkinson's disease. Mov Disord 15:127-131

Ritchie T, Noble EP (2003) Association of seven polymorphisms of the D2 dopamine receptor gene with brain receptor binding characteristics. Neurochem Res 28(1):73-82

Roberts E, Schilsky M (2008) Diagnosis and treatment of Wilson's disease an update. Hepatology 47:2089-2111

Samochowiec J, Ladehoff M, Pelz J et al (2000) Predominant influence of the 3-region of dopamine D2 receptor gene (DRD2) on the clinical phenotype in German alcoholics. Pharmacogenetics 10:471-475

Schiefermeier M, Kollegger H, Madl C et al (2000) The impact of apolipoprotein $\mathrm{E}$ genotypes on age at onset of symptoms and phenotypic expression in Wilson's disease. Brain 123:585-590

Schilsky ML, Scheinberg IH, Sternlieb I (1994) Liver transplantation for Wilson's disease: indications and outcome. Hepatology 19:583-587

Schlaug G, Hefter H, Nebeling B et al (1994) Dopamine D2 receptor binding and cerebral glucose metabolism recover after d-penicillamine-therapy in Wilson's disease. J Neurol 241:577-584 
Seniow J, Bak T, Gajda J, Poniatowska R (2002) Członkowska A (2002) Cognitive functioning in neurologically symptomatic and asymptomatic forms of Wilson's disease. Mov Disord 17:1077-1108

Simon I, Schaefer M, Reichert J, Stremmel W (2008) Analysis of the human Atox 1 homologue in Wilson patients. World J Gastroenterol 14(15):2383-2387

Stapelbroek JM, Bollen CW, van Amstel JK et al (2004) The H1069Q mutation in ATP7B is associated with late and neurologic presentation in Wilson's disease: results of meta-analysis. J Hepatol 41(5):758-763

Suzuki A, Kondo T, Otani K et al (2001) Association of the Taq1 A polymorphism of the dopamine D2 receptor gene with predisposition to neuroleptic malignant syndrome. Am J Psychiatry 158:1714-1716

Tan EK, Tan Y, Chai A et al (2003) Dopamine receptor Taq1A and Taq1B polymorphisms in Parkinson's disease. Mov Disord 18(5):593-601

Thompson J, Thomas N, Singleton A et al (1997) D2 dopamine receptor gene (DRD2) Taq 1 A polymorphism: reduced dopamine D2 receptor binding in the human striatum associated with the A1 allele. Pharmacogenetics 6:479-484
Tinsley RB, Bye C, Parish CL, Tziotis-Vais A, George S, Culvenor JG (2009) Dopamine D2 receptor knockout mice develop features of Parkinson's disease. Ann Neurol 66:472-484

Weiss KH, Merle U, Schaefer M, Ferenci P, Fullekrug J, Stremmel W (2006) Copper toxicosis gene MURR1 is not changed in Wilson disease patients with normal blood ceruloplasmin levels. World $\mathrm{J}$ Gastroenterol 12(14):2239-2242

Weiss KH, Runz H, Noe B et al (2010) Genetic analysis of BIRC4/ $\mathrm{XIAP}$ as a putative modifier gene of Wilson disease. J Inherit Met Dis. doi:10.1007/s10545-010-9123-5

Westermark K, Tedroff J, Thuoms KA et al (1995) Neurological Wilson's disease studied with magnetic resonance imaging and with positron emission tomography using dopaminergic markers. Mov Disord 10:596-603

Wu SN, Gao R, Xing QH et al (2006) Association of DRD2 polymorphisms and chlorpromazine-induced extrapyramidal syndrome in Chinese schizophrenic patients. Acta Pharmacol Sin 8:966-970

Vallone D, Picetti R, Borreli E (2000) Structure and function of dopamine receptors. Neurosci Biobehav Rev 24:125-132

Zhang JP, Lencz T, Malthora AK (2010) D2 receptor genetic variation and clinical response to antipsychotic drug treatment: a metaanalysis. Am J Psychiatry 167:763-772 